\title{
THERMODYNAMIC AND ADSORPTION ISOTHERM OF N,N'-BIS(2,4,6-TRIHYDROXYACETOPHENONE)- 2,2-DIMETHYLPROPANDIIMINE AS A CORROSION INHIBITOR ON SA-210 STEEL IN ALKALINE NACL SOLUTION
}

\author{
J. DAHDELE, I. DANAEE*, G.R. RASHED \\ Abadan Faculty of Petroleum Engineering, Petroleum University of Technology, Abadan, Iran
}

\begin{abstract}
Adsorption isotherm of $\mathrm{N} \mathrm{N}^{\prime}$-bis(2,4,6-trihydroxyacetophenone)-2,2-dimethylpropandiimine (THAPDP) as an environmentally friendly Salen Ligand corrosion inhibitor on mild steel was studied in alkaline solution $(\mathrm{pH}=10)$ containing $3 \% \mathrm{NaCl}$. Measurements were carried out using electrochemical and surface techniques. Potentiodynamic polarization curves suggested that this compound was an effective corrosion inhibitor for mild steel and the protection efficiency was increased with the increase in inhibitor concentration. The experimental results indicated that this organic compound was a mixed-type inhibitor. Adsorption on the mild steel surface followed the Langmuir isotherm model. Activation parameters and thermodynamic adsorption parameters of the corrosion process such as $E_{\mathrm{a}}, \Delta H, \Delta S, K_{\mathrm{ads}}$, and $\Delta G_{\text {ads }}$ were calculated at different temperatures.
\end{abstract}

Keywords: Corrosion, Inhibitor, Adsorption isotherm, Langmuir, Salen ligand.

\section{INTRODUCTION}

Carbon steel has been widely used under different conditions in various industries [1]. One of the known applications of mild steel is to being used in the steam boiler of the power plants [2]. The corrosion rate of mild steel is remarkably dependent on the chemical composition of the aqueous media in which the metal surface is exposed. Feedwater $\mathrm{pH}$ is one of the chemistry parameters that affects corrosion, and for an all-steel feedwater system, typically the more alkaline solution, $\mathrm{pH}>9.2$ up to about 10 , is convenient. In practice corrosion can never be stopped but hindered to a reasonable level. Corrosion prevention systems favor the use of corrosion inhibitors with low or zero environmental impacts. A corrosion inhibitor is a chemical substance that, upon addition to a corrosive environment, results in the decrease of corrosion rate to an acceptable level. Most of the well-known inhibitors are organic compounds which mainly contain heteroatoms such as oxygen, nitrogen or sulphur, and multiple bonds, which allow an adsorption on the metal surface [3-8]. The resultant film of chemisorbed inhibitor is responsible for protection either by physically blocking the surface from the corrosion environment or by retarding the electrochemical processes. These compounds are often simultaneously affected on both anodic and cathodic corrosion reactions. Therefore, they are sometimes referred to as mixed-type corrosion inhibitors [8-11]. The planarity and the lone electron pairs in the heteroatoms, are important features that determine the adsorption of these molecules on the metallic surface [12].

The aim of this work is to investigate the use of THAPDP as an environmentally friendly inhibitor for the corrosion of mild steel in alkaline solution $(\mathrm{pH}=10)$ containing $3 \% \mathrm{NaCl}$ evaluated by Tafel polarization data. The effect of temperature and concentration on corrosion inhibition were studied. Thermodynamic parameters were calculated from experimental data of the inhibition process at different temperatures.

\section{EXPERIMENTAL}

\subsection{Material preparation}

All chemicals were prepared from reagent-grade Merck product without further purification. The THAPDP Salen ligand (Fig. 1) was provided in high yeild $(95 \%)$ by the condensation of 2,4,6-trihydroxyacetophenone monohydrate $(0.372 \mathrm{~g}, 2 \mathrm{mmol})$ with 2,2-dimethylpropylenediamine $(0.102 \mathrm{~g}, 1 \mathrm{mmol})$ in a stirred ethanolic solution and heated to reflux for $2 \mathrm{~h}$ according to the described procedure [6]. The resulting precipitate was filtered off, washed with warm ethanol and diethyl ether. Identification of structure of synthesized Salen ligand was performed by IR and ${ }^{1} \mathrm{HNMR}$ spectroscopy and elemental analysis.<smiles>CC(=NCC(C)(C)CN=C(C)c1c(O)cc(O)cc1O)c1c(O)cc(O)cc1O</smiles>

Figure 1: Chemical structure of THAPDP.

The working electrodes were provided from steel SA-210 specimens of the following chemical composition (wt. \%): $0.27 \% \mathrm{C}, 0.1 \% \mathrm{Si}, 0.93 \% \mathrm{Mn}$, $0.048 \% \mathrm{P}, 0.058 \% \mathrm{~S}$ and the remainder Fe. To prepare working electrode, steel samples $(1 \mathrm{~cm} \times 1 \mathrm{~cm} \times 0.2 \mathrm{~cm})$ were mounted in polyester in such a way that only $1 \mathrm{~cm}^{2}$ of electrode was in contact with aggressive solution. The exposed area of the electrodes were mechanically abraded with 220, 600, 1000 and 2000 grades of emery paper, degreased with acetone and rinsed with distilled water before each electrochemical experiment.

All solutions were provided from analytical grade reagents and distilled water. The aqueous medium was provided containing $30 \mathrm{~g} / 1 \mathrm{NaCl}$ with different concentrations of inhibitor. $\mathrm{pH}$ value of solutions were finally adjusted to 10 by using $\mathrm{NaOH}$. The concentration range of inhibitors was varied from $1 \times 10^{-6}$ to $1 \times 10^{-4} \mathrm{M}$.

\subsection{Electrochemical measurements}

Polarization experiments were performed using a Compact-stat from IVIUM Technologies controlled by a Windows-based PC running dedicated software. A three-electrode glass cell was used consisting of a platinum electrode as counter, and a saturated calomel electrode (SCE) as a reference. The working electrode was immersed in the test cell at open circuit potential $\left(E_{\text {OCP }}\right)$ for 30 min before each experiment until steady state condition was reached. The potentiodynamic polarization was performed by scanning the potential at constant sweep rate of $1 \mathrm{mV} \mathrm{s}^{-1}$. The electrochemical cells were placed in a Faradaic cage to avoid electromagnetic disturbance from external sources. All tests were done at constant temperatures by controlling the cell temperature using a water bath. Fresh solution and fresh steel samples were used for each sweep. At least three measurements were carried out to ensure the reliability and reproducibility of the data. Stern-Geary equation is used to calculate the corrosion current $[13,14]$ :

$$
I_{\text {corr }}=\frac{b_{a} b_{c}}{2.303\left(\mathrm{~b}_{a}+b_{c}\right)}\left(\frac{1}{R_{p}}\right)
$$

where $b_{\mathrm{a}}$ and $b_{\mathrm{c}}$ are the anodic and cathodic slops respectively and $R_{\mathrm{p}}$ is the polarization resistance.

The steel specimens were grinded with emery papers, degreased in 
acetone, rinsed with distilled water and dried at room temperature. Then they were immersed in the test media with and without $1 \times 10^{-4} \mathrm{M}$ inhibitor for 48 h. Immediately after the immersion time was completed, the samples were subjected to SEM studies to know the surface morphology. Samples were observed by the Scanning Electron Microscopy (VEGA\ITESCAN) at 3000× magnification.

\section{RESULTS AND DISCUSSION}

\subsection{Potentiodynamic Polarization Measurements}

The polarization curves for mild steel in the alkaline media without and with various concentrations of inhibitor at $298 \mathrm{~K}$ are presented in Fig. 2. The

electrochemical corrosion parameters such as corrosion current density $\left(I_{\text {cor }}\right)$, corrosion potential ( $E_{\text {corr }}$ versus SCE), cathodic and anodic Tafel slopes $(b, b c)$ the degree of surface coverage $(\theta)$ and the inhibition efficiency $(I E \%=\theta \times 100)$ obtained by extrapolation of the Tafel lines [15] are shown in Table 1 . These results demonstrate that the compound act as an effective inhibitor for mild steel in alkaline $\mathrm{NaCl}$ solution. By using the following equation the degree of surface coverage for different concentrations of inhibitor is calculated [16-18]:

$$
\theta=\frac{\dot{I}_{\text {corr }}-I_{\text {corr }}}{\dot{I}_{\text {corr }}}
$$

Table 1: Potentiodynamic polarization parameters for the corrosion of mild steel in alkaline $3 \% \mathrm{NaCl}(\mathrm{PH}=10)$ without and with different concentrations of inhibitor at $298 \mathrm{~K}$.

\begin{tabular}{|c|c|c|c|c|c|c|c|}
\hline $\begin{array}{c}C \\
/ \mu \mathrm{M}\end{array}$ & $\begin{array}{c}E_{\text {corr }} \\
/ \mathrm{mV}\end{array}$ & $\begin{array}{c}I_{\text {corr }} \\
/ \mu \mathrm{A} \mathrm{cm}\end{array}$ & $\begin{array}{c}-b_{\mathrm{c}} \\
/ \mathrm{mV} \mathrm{dec}^{-1}\end{array}$ & $\begin{array}{c}b_{\mathrm{a}} \\
/ \mathrm{mV} \mathrm{dec}^{-1}\end{array}$ & $\begin{array}{c}R_{\mathrm{p}} \\
/ \mathrm{ohm}\end{array}$ & $\theta$ & $I E \%$ \\
\hline blank & -738.6 & 7 & 66 & 84 & 2304 & - & - \\
\hline 1 & -710.4 & 5.88 & 68 & 79 & 2686 & 0.16 & 16 \\
\hline 5 & -701.8 & 3.59 & 52 & 62 & 3425 & 0.48 & 48.71 \\
\hline 10 & -757.2 & 3.5 & 34 & 42 & 2338 & 0.5 & 50 \\
\hline 30 & -680.3 & 3.16 & 68 & 87 & 5222 & 0.54 & 54.85 \\
\hline 70 & -721.2 & 3 & 33 & 31 & 2338 & 0.57 & 57.14 \\
\hline 100 & -673.9 & 2.55 & 68 & 77 & 6164 & 0.63 & 63.57 \\
\hline
\end{tabular}

where $\dot{I}_{\text {anr }}$ and $I_{\text {cor }}$ are the uninhibited and inhibited corrosion current densities respectively. Both cathodic and anodic reactions suppressed by the addition of inhibitor (Figure 2). $I_{\text {corr }}$ decreases remarkably, while $\theta$ increases with the inhibitor concentration. No definite trend was observed corrosion potential $\left(E_{\text {corr }}\right)$ shift which revealed the mixed type inhibitor, with the inhibitory action caused by a geometric blocking effect [19].

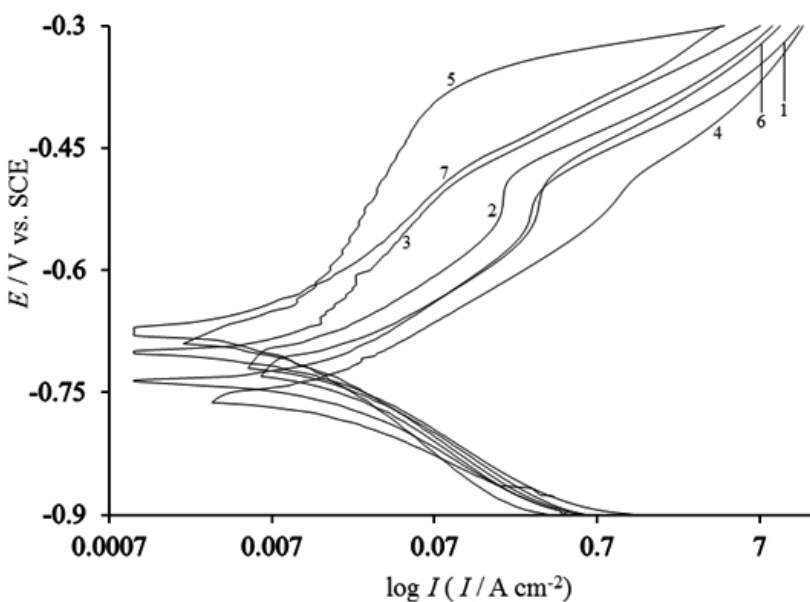

Figure 2: Polarization curves for mild steel in alkaline $3 \% \mathrm{NaCl}(\mathrm{pH}=10)$ without and with various concentrations of inhibitor at $298 \mathrm{~K}$. 1) Blank, 2) $\left.1 \times 10^{-6}, 3\right) 5 \times 10^{-6}$, 4) $\left.\left.1 \times 10^{-5}, 5\right) 3 \times 10^{-5}, 6\right) 7 \times 10^{-5}$, 7) $1 \times 10^{-4}$.

\subsection{Effect of Temperature}

To evaluate the adsorption of THAPDP and activation parameters of the corrosion processes of steel, the effect of temperature was investigated on inhibited solution-metal reaction (Figs. 3\&4). The electrochemical corrosion parameters extracted from polarization curves are presented in Tables $2 \& 3$ at $318 \mathrm{~K}$ and $338 \mathrm{~K}$ respectively. As can be seen, $I_{\text {corr }}$ increases by increasing temperature. Arrhenius equation expressed the relationship between the corrosion rate and temperature [20]:

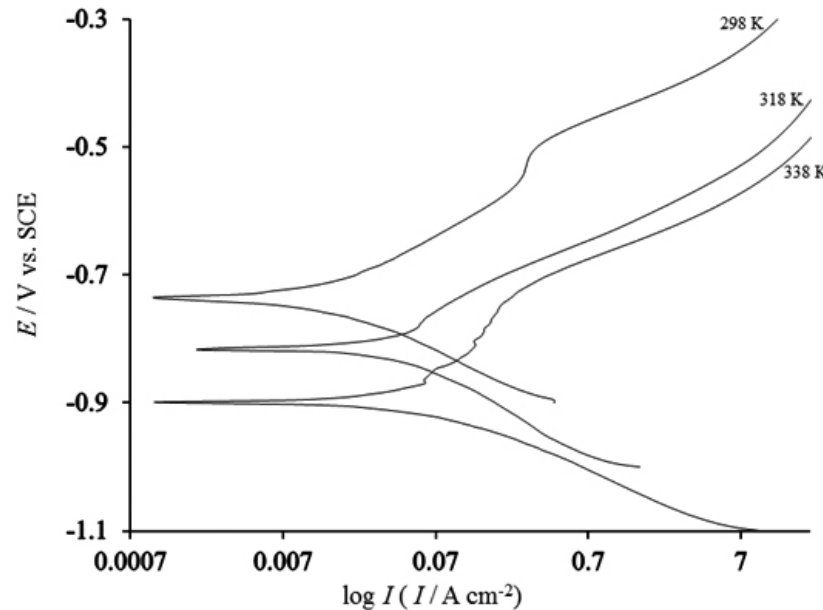

Figure 3: Anodic and cathodic polarization curves for mild steel in alkaline $3 \% \mathrm{NaCl}(\mathrm{pH}=10)$ without inhibitor at different temperatures: $298 \mathrm{~K}$, $318 \mathrm{~K}$ and $338 \mathrm{~K}$.

$$
\ln I_{\text {corr }}=\ln A-\frac{E_{a}}{R T}
$$

where $A$ is the frequency factor, $E_{\mathrm{a}}$ is the apparent activation energy, $T$ is the absolute temperature and $R$ is the gas constant.

From $\ln I_{\text {corr }}$ vs. $T^{-1}$ (Fig. 5), the $E_{\mathrm{a}}$ value was obtained as $32.24 \mathrm{~kJ} \mathrm{~mol}^{-}$ ${ }^{1}$ in the absence of inhibitor while in the presence of $1 \times 10^{-4} \mathrm{M}$ of inhibitor was $19.48 \mathrm{~kJ} \mathrm{~mol}^{-1}$. It has been reported that the decrease in $E_{\mathrm{a}}$ with inhibitor concentration (Table 4) is typical of chemisorption and its physisorptions is pronounced in the opposite case. Also the decrease in activation energy of corrosion at higher concentration of inhibitor attributed to a shift of the net corrosion reaction from that on the uncovered part on the metal surface to the covered one [21]. Enthalpy and entropy of activation are calculated by using the formula [22]: 


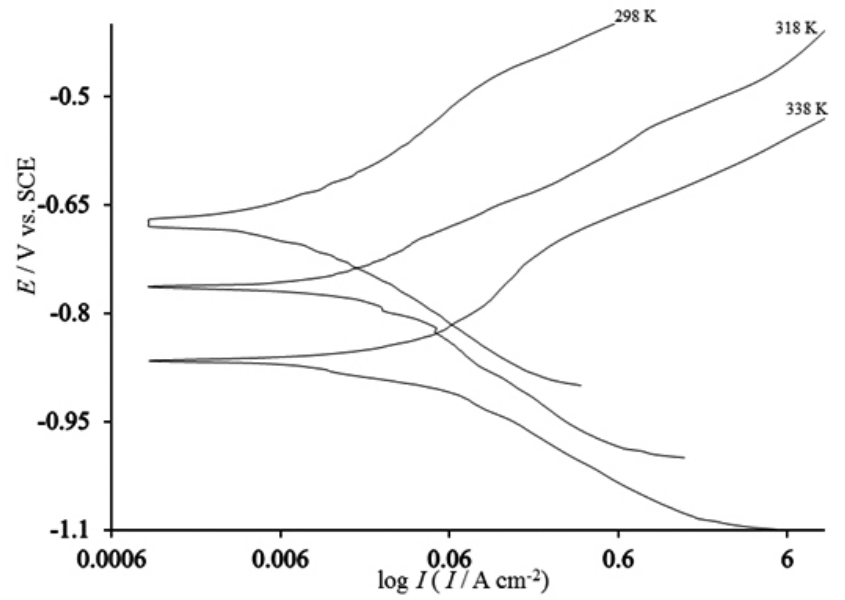

Figure 4: Anodic and cathodic polarization curves for mild steel in alkaline $3 \% \mathrm{NaCl}(\mathrm{pH}=10)$ with $1 \times 10^{-4} \mathrm{M}$ of inhibitor at different temperatures: $298 \mathrm{~K}, 318 \mathrm{~K}$ and $338 \mathrm{~K}$.

Table 2: Potentiodynamic polarization parameters for the corrosion of mild steel in alkaline $3 \% \mathrm{NaCl}(\mathrm{PH}=10)$ without and with different concentrations of inhibitor at $318 \mathrm{~K}$.

\begin{tabular}{|c|c|c|c|c|c|c|c|}
\hline $\begin{array}{c}C \\
/ \mu \mathrm{M}\end{array}$ & $\begin{array}{c}E_{\text {corr }} \\
/ \mathrm{mV}\end{array}$ & $\begin{array}{c}I_{\text {corr }} \\
/ \mu \mathrm{Acm}^{-2}\end{array}$ & $\begin{array}{c}-b_{\mathrm{c}} \\
/ \mathrm{mV} \mathrm{dec}^{-1}\end{array}$ & $\begin{array}{c}b_{\mathrm{a}} \\
/ \mathrm{mV} \mathrm{dec}^{-1}\end{array}$ & $\begin{array}{c}R_{\mathrm{p}} \\
/ \mathrm{ohm}\end{array}$ & $\theta$ & $I E \%$ \\
\hline blank & -816.6 & 29.78 & 102 & 143 & 865.3 & - & - \\
\hline 1 & -805.1 & 14.92 & 69 & 86 & 1113 & 0.49 & 49.89 \\
\hline 5 & -804.6 & 10.86 & 52 & 76 & 1238 & 0.63 & 63.53 \\
\hline 10 & -826.5 & 9.715 & 43 & 68 & 1183 & 0.67 & 67.37 \\
\hline 30 & -816.3 & 5.465 & 34 & 36 & 1387 & 0.81 & 81.64 \\
\hline 70 & -805.7 & 4.607 & 43 & 19 & 1251 & 0.84 & 84.52 \\
\hline 100 & -765 & 3.823 & 21 & 34 & 1466 & 0.87 & 87.16 \\
\hline
\end{tabular}

Table 3: Potentiodynamic polarization parameters for the corrosion of mild steel in alkaline $3 \% \mathrm{NaCl}(\mathrm{PH}=10)$ without and with different concentrations of inhibitor at $338 \mathrm{~K}$.

\begin{tabular}{|c|c|c|c|c|c|c|c|}
\hline $\begin{array}{c}C \\
/ \mu \mathrm{M}\end{array}$ & $\begin{array}{c}E_{\text {corr }} \\
/ \mathrm{mV}\end{array}$ & $\begin{array}{c}I_{\text {corr }} \\
/ \mu \mathrm{Acm}^{-2}\end{array}$ & $\begin{array}{c}-b_{\mathrm{c}} \\
/ \mathrm{mV} \mathrm{dec}^{-1}\end{array}$ & $\begin{array}{c}b_{\mathrm{a}} \\
/ \mathrm{mV} \mathrm{dec}^{-1}\end{array}$ & $\begin{array}{c}R_{\mathrm{p}} \\
/ \mathrm{ohm}\end{array}$ & $\theta$ & $I E \%$ \\
\hline blank & -899.7 & 32.33 & 64 & 147 & 601.4 & - & - \\
\hline 1 & -889.3 & 17.7 & 48 & 61 & 658.6 & 0.45 & 45.25 \\
\hline 5 & -908.4 & 13.65 & 46 & 38 & 663.8 & 0.57 & 57.77 \\
\hline 10 & -909 & 11.83 & 55 & 56 & 1016 & 0.63 & 63.40 \\
\hline 30 & -903.3 & 10.09 & 42 & 48 & 957 & 0.68 & 68.79 \\
\hline 70 & -868.9 & 8.026 & 43 & 43 & 1156 & 0.75 & 75.174 \\
\hline 100 & -866.8 & 6.532 & 36 & 44 & 1317 & 0.79 & 79.79 \\
\hline
\end{tabular}

$$
I_{\text {cor }}=\left(\frac{R T}{N h}\right) \exp \left(\frac{\Delta s_{a}}{R}\right) \exp \left(\frac{-\Delta H_{a}}{R T}\right)
$$

where $h$ is Planks constant, $N$ is Avogadro's number, $\Delta S_{\mathrm{a}}$ is the entropy of activation, and $\Delta H$ is the enthalpy of activation. Fig. 6 indicates the plot of $\ln \left(I_{\text {corr }} / T\right)$ versus $1 / T$. Straight lines with a slope of $-\Delta H_{\mathrm{a}} / \mathrm{R}$ and an intercept of $(\ln R / N h+\Delta S / R)$ were drawn and the values of $\Delta H$ and $\Delta S$ were obtained in Table 4. The positive values of $\Delta H_{\mathrm{a}}$ revealed the endothermic nature of the steel dissolution process. Also the entropy of activation increased more negatively with increasing inhibitor concentrations. The negative value of $\Delta S$ indicated that a decrease in disordering takes place in going from reactants to the reaction complex. 


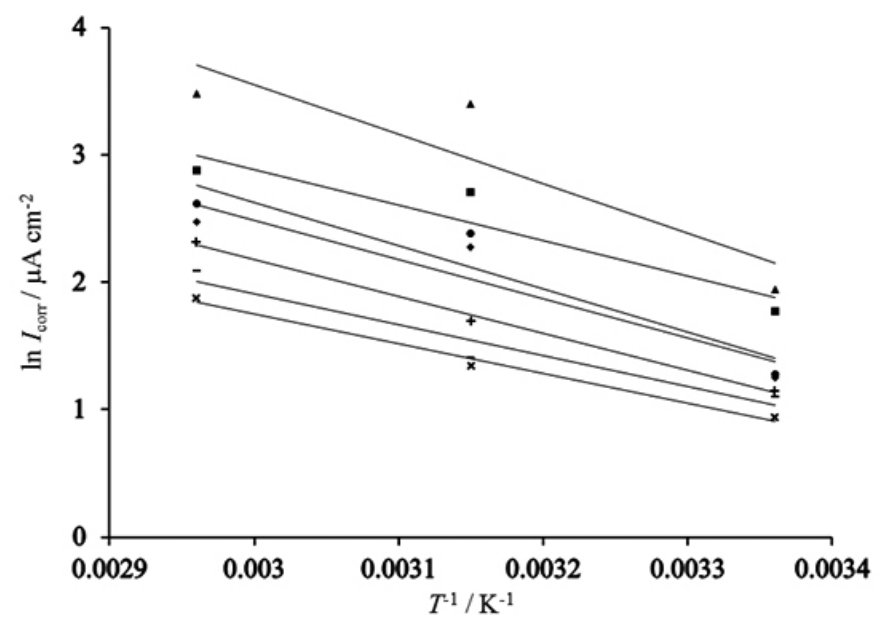

Figure 5: Typical Arrhenius plots of $\ln I_{\text {corr }}$ vs. $1 / T$ for mild steel in alkaline $3 \% \mathrm{NaCl}(\mathrm{pH}=10)$ at different concentrations of inhibitor: $\Delta)$ Blank, $\square) 1 \times 10^{-6}$, ○) $\left.\left.\left.\left.5 \times 10^{-6}, \diamond\right) 1 \times 10^{-5},+\right) 3 \times 10^{-5},-\right) 7 \times 10^{-5}, \times\right) 1 \times 10^{-4}$.

Table 4: Activation parameters of the dissolution of steel in alkaline media $(\mathrm{PH}=10)$ contaminated by $3 \% \mathrm{NaCl}$ in the absence and in the presence of inhibitor.

\begin{tabular}{|c|c|c|c|c|c|}
\hline $\begin{array}{c}C \\
\mu \mathrm{M}\end{array}$ & $\begin{array}{c}E_{\mathrm{a}} \\
/ \mathrm{kJ} \mathrm{mol}^{-1}\end{array}$ & $\begin{array}{c}A \\
/ \mathrm{A} \mathrm{cm}^{-2}\end{array}$ & $\begin{array}{c}\Delta H_{\mathrm{a}} \\
/ \mathrm{kJ} \mathrm{mol}^{-1}\end{array}$ & $\begin{array}{c}\Delta S_{\mathrm{a}} \\
/ \mathrm{J} \mathrm{mol}^{-1} \mathrm{k}^{-1}\end{array}$ & $\begin{array}{c}E \mathrm{a}-\Delta H \mathrm{a}=R T \\
/ \mathrm{kJ} \mathrm{mol}^{-1}\end{array}$ \\
\hline blank & 32.24 & 3925483.161 & 29.63 & -127.46 & 2.61 \\
\hline 1 & 23.14 & 76038.87487 & 20.53 & -160.17 & 2.61 \\
\hline 5 & 28.04 & 340782.5944 & 25.42 & -147.70 & 2.61 \\
\hline 10 & 25.57 & 121783.48 & 22.96 & -156.25 & 2.61 \\
\hline 30 & 24.08 & 52365.32947 & 21.47 & -163.27 & 2.61 \\
\hline 70 & 20.3 & 10273.26327 & 17.68 & -176.81 & 2.62 \\
\hline 100 & 19.48 & 6530.899751 & 16.87 & -180.58 & 2.61 \\
\hline
\end{tabular}

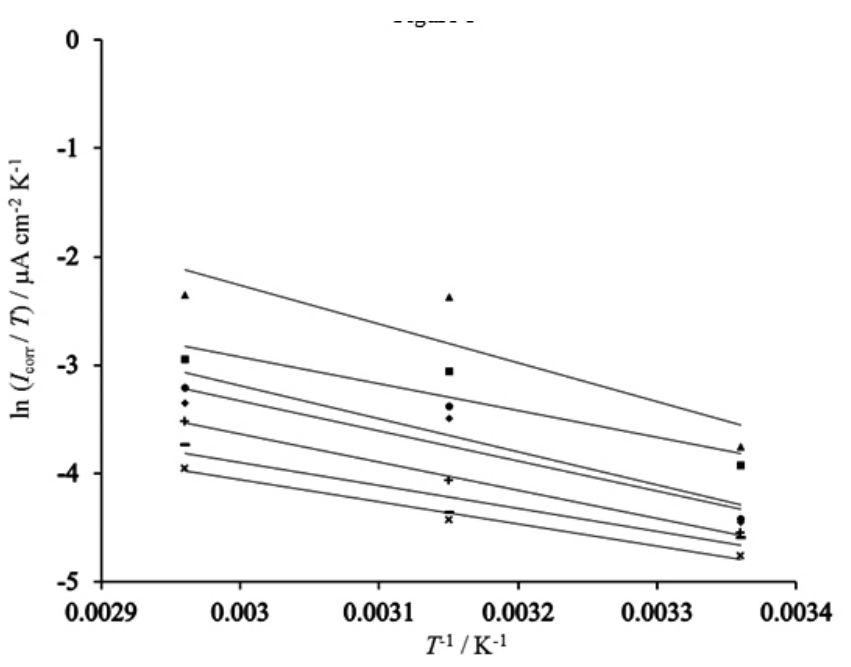

Figure 6: Typical Arrhenius plots of $\ln \left(I_{\text {corr }} / T\right)$ vs. $1 / T$ for mild steel in alkaline $3 \% \mathrm{NaCl}(\mathrm{pH}=10)$ at different concentrations of inhibitor: $\Delta)$ Blank, ㅁ) $1 \times 10^{-6}$, ○) $\left.\left.\left.\left.5 \times 10^{-6}, \diamond\right) 1 \times 10^{-5},+\right) 3 \times 10^{-5},-\right) 7 \times 10^{-5}, \times\right) 1 \times 10^{-4}$.

\subsection{Adsorption Isotherm}

It is generally agreed that corrosion inhibition is due to the adsorption of the inhibitor molecule at the metal-solution interface [23]. Adsorption isotherm importance is related to its information about the interaction between molecules and metal surface [24]. The values of surface coverage in different concentrations of the inhibitor were calculated from the polarization measurements in different temperature. The surface coverage values are used to determine graphically the various adsorption isotherms including Temkin, Langmuir, Frumkin, Freundlich, El-Awadys, Flory-Huggins and BockrisSwinkels. To choose the isotherm, the correlation coefficients $\left(R^{2}\right)$ were calculated and the best fit was obtained from the Langmuir isotherm $\left(\mathrm{R}^{2}>\right.$ 0.99). Langmuir isotherm is expressed by the following equation:

$$
\frac{C}{\theta}=\frac{1}{K_{a d s}}+C
$$

where $C$ is the inhibitor concentration in the solution and $K$ is the equilibrium constant of the inhibitor adsorption process. The plots of $C / \theta$ versus $C$ and its linear relationship are presented in Fig. 7. The straight line is obtained with slopes close to unity which indicated that the adsorption of THAPDP obeys Langmuir adsorption isotherm. Langmuir's adsorption assumes that each adsorbate occupy only one site on the metal surface and do not interact with the other adsorbate molecules [24]. The intercept of lines on the $C / \theta$-axis determined the adsorption equilibrium constant values. The standard free energy of adsorption is related with the standard adsorption equilibrium constant of the inhibitor by the following equation:

$$
\Delta G_{a d s}=-R T \ln \left(55.5 K_{a d s}\right)
$$




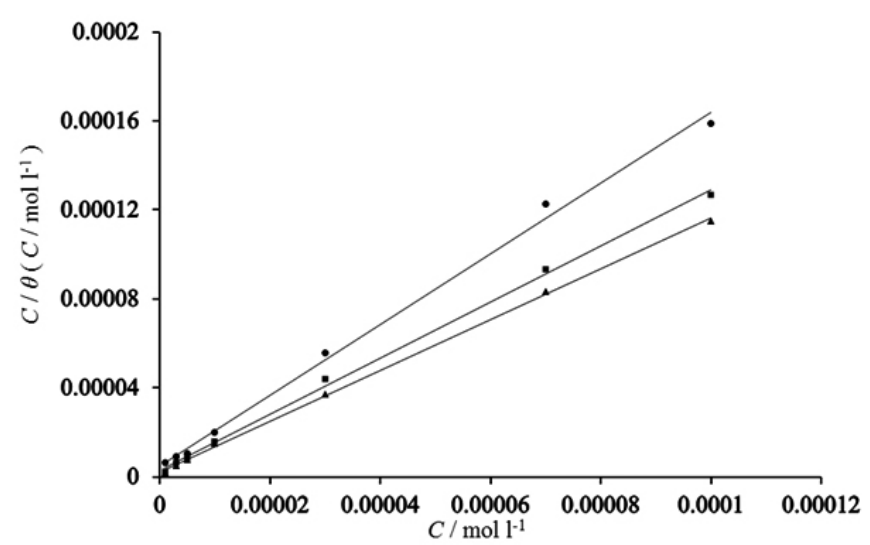

Figure 7: Langmuir adsorption isotherm $(C / \theta$ vs. $C)$ of inhibitor in alkaline $3 \% \mathrm{NaCl}(\mathrm{pH}=10)$ at different temperatures.

The constant value of 55.5 is the concentration of water in solution expressed in molar. The enthalpy and entropy of adsorption can be deduced from the following equations [20]:

$$
\begin{aligned}
& \Delta G_{a d s}=\Delta H_{a d s}-T \Delta S_{a d s} \\
& \ln K_{a d s}=-\frac{\Delta H_{a d s}}{R T}+\frac{\Delta S_{a d s}}{R}-\ln (55.5)
\end{aligned}
$$

By plotting $\ln K_{\text {ads }}$ versus $1 / T$, enthalpy and entropy of adsorption can be calculated. Straight lines with the intercept $\left[\Delta S_{\text {ads }} / R-\ln (55.5)\right]$ and the slope $-\Delta H_{\text {ads }} / R$ are attained. Table 5 shows the calculated values of the entropy and heat of adsorption. The positive value of $\Delta H$ equal to $11.04 \mathrm{~kJ} \mathrm{~mol}^{-1}$ reveals that the adsorption of THAPDP on the mild steel surface is an endothermic process which attributes to chemisorption process. The more water molecules desorbed from the metal surface by one inhibitor molecule adsorption led to increasing in entropy vale [14]. The negative sign of the standard free energy of adsorption indicates the tendency of adsorption of THAPDP on the metal surface, i.e., the inhibitor adsorption on the metal takes place spontaneously [25]. Values of $\Delta G_{\text {ads }}$ around $-20 \mathrm{~kJ} \mathrm{~mol}^{-1}$ or less negative involve the electrostatic interaction between organic charged molecules and the charged metal surface (physisorption); those around $-40 \mathrm{~kJ} \mathrm{~mol}^{-1}$ or more negative are consistent with charge sharing or transfer from the organic molecules to the metal surface to form a co-ordinate type of bond (chemisorption) [26]. The values of $\Delta G_{\text {ads }}$ were more negative than $-40 \mathrm{~kJ} \mathrm{~mol}^{-1}$, therefore the adsorption process was chemisorption.

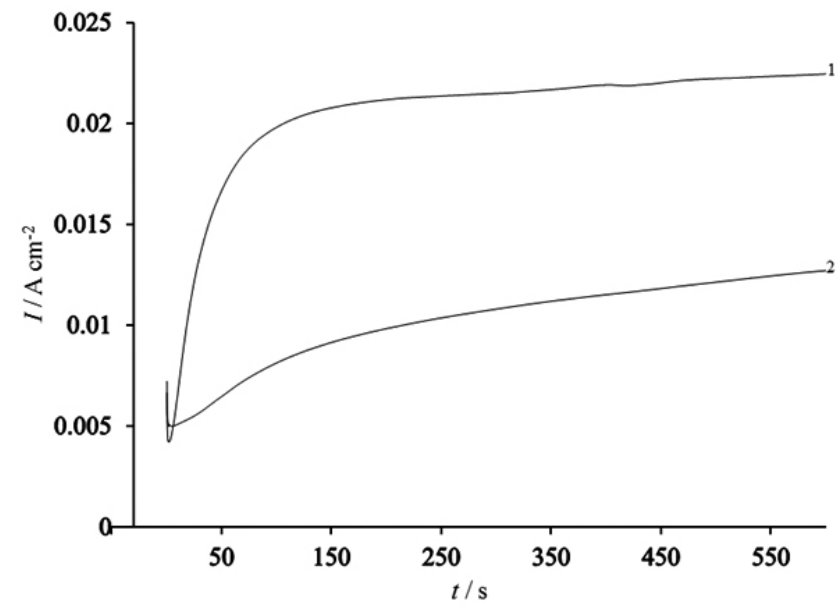

Figure 8: Current transients of steel electrode at -0.3 V vs. SCE. (1) Blank, (2) $1 \times 10^{-4} \mathrm{M}$ of inhibitor.

\subsection{Chronoamperometry}

The chronoamperometric technique was used in order to gain more insight about the ability of the THAPDP to inhibit the corrosion process of the mild steel. The electrode was polarized anodically at $-0.3 \mathrm{~V}$ versus SCE for $600 \mathrm{~s}$. Fig. 8 shows the current density values associated with the electrooxidation of mild steel which recorded in the absence and in the presence inhibitor. Initially, the current decreases with time. The decrease in the current density was due to the formation of corrosion products layer on the anode surface. However, in later times the current increases to reach a steady state value depending on applied potential. The increase in current is related to the dissolution of the steel and pit nucleation and growth. As can be seen, the current density decreases considerably in the presence of the inhibitor.

\subsection{Surface analysis}

The inhibition effect of THAPDP on corrosion reaction was studied by the SEM images of corroded mild steel surface in the absence and presence of inhibitor (Fig. 9). It can be seen that the metal surface in the blank solution (without inhibitor) corrode uniformly (Fig. 9A) and it is strongly protected using inhibitor (Fig. 9B). These micrographs shows that the smoothness of the tested metal has remarkably improved in presence of the inhibitor in comparison with the blank. The smoothening of the surface caused by the adsorption of inhibitor molecules on the metal surface and blocking the exposure surface from aggressive solution.
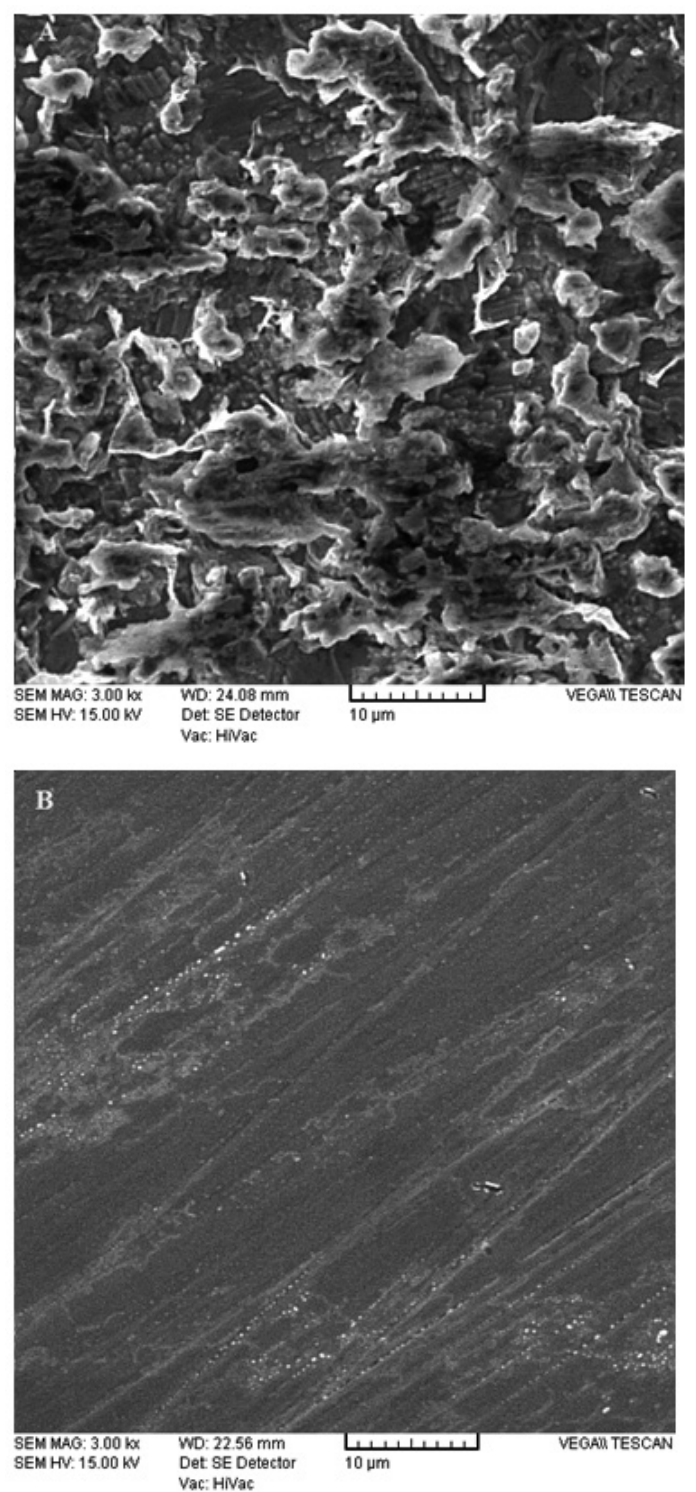

Figure 9: SEM micrographs of the mild steel surfaces after $48 \mathrm{~h}$ immersion period in the blank (A) and $1 \times 10^{-4} \mathrm{M}$ of inhibitor (B) with magnification of 3000 . 
Table 5: Thermodynamic and equilibrium adsorption parameters for adsorption of THAPDP on mild steel surface in alkaline $3 \% \mathrm{NaCl}(\mathrm{PH}=10)$.

\begin{tabular}{|c|c|c|c|c|c|c|c|}
\hline \multicolumn{3}{|c|}{$K_{\text {ads }} / 1 \mathrm{~mol}^{-1}$} & \multicolumn{3}{c|}{$\Delta G_{\text {ads }} / \mathrm{kJ} \mathrm{mol}^{-1}$} & \multirow{\Delta}{\DeltaH_{\text{ads}}}{} & $\begin{array}{c}\Delta S_{\text {ads }} \\
/ / \mathrm{JJ} \\
\mathrm{mol}^{-1} \\
\mathrm{~mol}^{-1} \\
\mathrm{k}^{-1}\end{array}$ \\
\hline $298 \mathrm{~K}$ & $\begin{array}{c}318 \\
\mathrm{~K}\end{array}$ & $338 \mathrm{~K}$ & $298 \mathrm{~K}$ & $318 \mathrm{~K}$ & $338 \mathrm{~K}$ & &
\end{tabular}

\section{CONCLUSION}

$\mathrm{N}, \mathrm{N}^{\prime}$-bis(2,4,6-trihydroxyacetophenone)-2,2-dimethylpropandiimine (THAPDP) was investigated as an environmentally friendly Salen Ligand for corrosion inhibition of SA-210 steel in alkaline solution with different concentrations using a series of techniques. The THAPDP showed inhibition effect for mild steel corrosion in alkaline $3 \% \mathrm{NaCl}$ solution. Moreover, with increasing inhibitor concentration, the inhibition efficiency increased because of the film formation on the metal surface. Electrochemical polarization measurements indicated that the inhibitor system acted as a mixed type inhibitor. Also the adsorption of the inhibitor molecules on metal surface obeyed the Langmuir adsorption isotherm. The value of $\Delta G_{\text {ads }}$ showed that the adsorption occurred through chemisorption. Thermodynamic parameters revealed the spontaneous adsorption process. The SEM studies showed that the steel surface with inhibitor molecules looked smoother and more uniform with lower roughness than that in the uninhibited solution.

\section{REFERENCES}

1.- D. Özkir, Emel Bayol, A. A. Gurten, Y. Surme, J. Chil. Chem. Soc.,58, 2158, (2013).

2.- A. Banweg, Boiler and Feedwater Treatment. Sheir's Corrosion, 4, 2971, (2010).

3.- F. B. Ravari, A. Dadgareenezhad, J. Chil. Chem. Soc., 58, 1853, (2013).

4.- S. P. Fakrudeen, A. Murthyh. C, B. Raju V, J. Chil. Chem. Soc., 57, 1364, (2012).

5.- I. Danaee, O. Ghasemi, G. R. Rashed, M. RashvandAvei, M. H. Maddahy, J. Mol. Struct. 1035, 247, (2013).
6.- H. Jafari, I. Danaee, H. Eskandari, M. RashvandAvei, Ind. Eng. Chem. Res., 52, 6617, (2013).

7.- A.A. Khadom, A.S. YARO, A.A.H. Kadhum, J. Chil. Chem. Soc., 55, 150, (2010).

8.- U. A. KINI, P. Shetty, S. D. Shetty, A. Isloor, R. Herle, J. Chil. Chem. Soc., 55, 56, (2010). [9] A.S. Fouda, H. Mahfouz, J. Chil. Chem. Soc., 54, 408, (2009).

10.- B. Gómez, N. V. Likhanova, M. A. Domínguez Aguilar, O. Olivares, J. M. Hallen, J. M. Martínez-Magadán, J. Phys. Chem. 109, 8950 (2005).

11.- M. Guzman, R. Lara, L. Vera, J. Chil. Chem. Soc., 54, 123, (2009).

12.- S. Kumar, S. Arora, M. Sharma, P. Arora, S. P. Mathur, J. Chil. Chem. Soc., 54, 83, (2009).

13.- O. Ghasemi, I. Danaee, G.R. Rashed, M. RashvandAvei, M.H. Maddahy, J. Cent. South Univ. 20, 301, (2013).

14.- M. Gholami, I. Danaee, M.H. Maddahy, M. RashvandAvei, Ind. Eng. Chem. Res. 52, 14875, (2013).

15.- T. Sethi, A. Chaturvedi,R.K. Upadhyay, S.P. Mathur, J. Chil. Chem. Soc., 52, 1206, (2007).

16.- S. D. Shetty, P. Shetty, H. V. S. Nayak, J. Chil. Chem. Soc., 51, 849, (2006).

17.- P.B. Raja, A. A. Rahim, H. Osman, K. Awang, Acta Phys. Chim. Sin., 26, 2171, (2010).

18.- S.M.A. Hosseini, A. Azimi, Mater. Corros., 59, 41, (2008).

19.- I.B. Obot, N.O. Obi-Egbedi, Corros. Sci., 52, 198, (2010).

20.- A.R. Hoseinzadeh, I. Danaee, M.H. Maddahy, J. Mater. Sci. Technol., 29, 884, (2013).

21.- L. Olen, J.R. Riggs, M. Ray; Corrosion 23, 252, (1976).

22.- L. Herrag, A. Chetouani, S. Elkadiri, B. Hammouti, A. Aouniti, Portugal. Ectrochim. Acta, 26, 211, (2008).

23.- A. Dadgarinezhad, F. Baghaei, J. Chil. Chem. Soc., 54, 208, (2009).

24.- F. B. Ravri, A. Dadgarinezhad, I. Shekhshoaei, J. Chil. Chem. Soc., 54, 302, (2009).

25.- Roberge, P.R. Corrosion Engineeing principles and practice. McGrawHill, 2008, 49-50.

26.- A.R. Hoseinzadeh, I. Danaee, M.H. Maddahy, Z. Phys. Chem. 227, 403, (2013). 